ISSN 1420-3049

www.mdpi.com/journal/molecules

Article

\title{
Essential Oil Composition of Stems and Fruits of Caralluma europaea N.E.Br. (Apocynaceae)
}

Pietro Zito ${ }^{1}$, Maurizio Sajeva ${ }^{1, *}$, Maurizio Bruno ${ }^{2}$, Antonella Maggio ${ }^{2}$, Sergio Rosselli ${ }^{2}$, Carmen Formisano ${ }^{3}$ and Felice Senatore ${ }^{3}$

1 Dipartimento di Scienze Botaniche, Università degli Studi di Palermo, Via Archirafi 38, I-90123 Palermo, Italy

2 Dipartimento di Chimica Organica, Università degli Studi di Palermo, Viale delle Scienze, Parco d’Orleans II, I-90128 Palermo, Italy

3 Dipartimento di Chimica delle Sostanze Naturali, Università degli Studi di Napoli "Federico II”, Via D. Montesano, 49, I-80131 Napoli, Italy

* Author to whom correspondence should be addressed; E-Mail: sajeva@unipa.it; Tel.: +39-091-623-8247; Fax: +39-091-623-8203.

Received: 30 December 2009; in revised form: 19 January 2010 / Accepted: 22 January 2010 / Published: 27 January 2010

\begin{abstract}
The essential oil of the stems and fruits of Caralluma europaea (Guss.) N.E.Br. (Apocynaceae) from Lampedusa Island has been obtained by hydrodistillation and its composition analyzed. The analyses allowed the identification and quantification of 74 volatile compounds, of which 16 were aromatic and 58 non-aromatic. Stems and fruits contained $1.4 \%$ and $2.7 \%$ of aromatic compounds respectively, while non-aromatic were $88.3 \%$ and $88.8 \%$. Non-aromatic hydrocarbons were the most abundant compounds in both organs, followed by fatty acids. Data showed differences in the profiles between stems and fruits which shared only eighteen compounds; stems accounted for 38 compounds while fruits for 53. Fruits showed a higher diversity especially in aromatic compounds with twelve versus four in stems. Among the volatiles identified in stems and fruits of $C$. europaea 26 are present in other taxa of Apocynaceae, 52 are semiochemicals for many insects, and 21 have antimicrobial activity. The possible ecological role of the volatiles found is briefly discussed.
\end{abstract}


Keywords: antimicrobial; Apocynaceae; Caralluma europaea; essential oils; semiochemicals

\section{Introduction}

Volatile compounds with different ecological roles are widely produced by plants. The review by Dudereva et al. [1] indicates the different roles, such as pollinator attraction, defence from phytophagous and pathogenic microbes, allelopathy, seed dispersal, and thermotolerance, among others. There are few studies on the chemical composition of the genus Caralluma. The presence of pregnane steroids in several species of Caralluma has been reported in previous chemical studies [2-5] and it could indicate a systematical importance within the genus. On the other hand only a few species have shown the occurrence of flavonoids [6-8] and the only paper published on the chemical constituents of Caralluma europaea (Guss.) N.E.Br. is that of Meve and Heneidak [9]. Recently Formisano et al. [10] analysed the chemical volatiles composition by headspace of C. europaea and discussed their possible role in the biology of pollination linked to the sapromyiophilous syndrome typical of the Stapeliads. Caralluma europaea [= Apteranthes europaea (Guss.) Plowes] is a stemsucculent member of Apocynaceae - Asclepiadoideae, distributed in Egypt, S. Spain, Italy (Lampedusa Island), Libya, Tunisia, Algeria and Morocco [9]. It has quadrangular stems and forms large clumps up to 15-20 cm in diameter, flowers are red-brown with yellow stripes or strikes, 10-15 $\mathrm{mm}$ in diameter, and the corona is normally purplish [11]. Fruits are dehiscent follicles up to $20 \mathrm{~cm}$ long which at maturity release wind-dispersed seeds. To the best of our knowledge, no phytochemical studies on the essential oil of any species of Caralluma have been reported so far. In the present paper we present data on the essential oil composition of stems and fruits of $C$. europaea by hydrodistillation and compare the results with data available in scientific literature.

\section{Results and Discussion}

The analysis by GM/MS allowed the identification of 74 volatile compounds of which 16 aromatic and 58 non-aromatic (Table 1). Stems (S) and fruits (F) contained $1.4 \%$ and $2.7 \%$ of aromatic compounds respectively, while non-aromatic were $88.3 \%$ and $88.8 \%$.

Table 1. Percent composition of the essential oils of stems (S) and fruits (F) of Caralluma europaea (Guss) N.E.Br.

\begin{tabular}{|c|c|c|c|c|c|}
\hline$K_{i 1}{ }^{a}$ & $\mathbf{K}_{\mathbf{i} 2}{ }^{\mathbf{b}}$ & Ident. $^{c}$ & Compounds & S \% & F \% \\
\hline 800 & 800 & $1,2,3$ & Octane & 0.3 & \\
\hline 901 & & 1,2 & Heptanal & & $\mathrm{t}$ \\
\hline 936 & 1075 & $1,2,3$ & $\alpha$-Pinene & & 0.4 \\
\hline 963 & 1543 & $1,2,3$ & Benzaldehyde & & 0.3 \\
\hline 980 & 1454 & 1,2 & 1-Octen-3-ol & & 0.6 \\
\hline 1001 & & 1,2 & Octanal & & 0.1 \\
\hline 1002 & & 1,2 & 2-Pentylfuran & & 0.1 \\
\hline 1044 & 1663 & $1,2,3$ & Phenylacetaldehyde & & 0.6 \\
\hline
\end{tabular}


Table 1. Cont.

\begin{tabular}{|c|c|c|c|c|c|}
\hline 1058 & 1657 & $1,2,3$ & Acetophenone & & $\mathrm{t}$ \\
\hline 1097 & & 1,2 & Methyl benzoate & & 0.1 \\
\hline 1102 & & 1,2 & Nonanal & & $\mathrm{t}$ \\
\hline 1167 & 1734 & 1,2 & 4-Ethyl benzaldehyde & & \\
\hline 1179 & 1763 & $1,2,3$ & Naphtalene & $\mathrm{t}$ & \\
\hline 1197 & & 1,2 & Safranal & & 0.2 \\
\hline 1206 & 1508 & 1,2 & Decanal & & 0.4 \\
\hline 1208 & & 1,2 & $\alpha$-Ionene & 0.7 & $\mathrm{t}$ \\
\hline 1212 & & 1,2 & $\beta$-Cyclocitral & & 0.1 \\
\hline 1243 & & 1,2 & 1,2,3,4-tetrahydro-1,5,7-trimethylnaphthalene & & $\mathrm{t}$ \\
\hline 1261 & & 1,2 & (E)-2-Decenal & & 0.3 \\
\hline 1291 & 2471 & $1,2,3$ & Indole & 0.6 & \\
\hline 1306 & & 1,2 & Undecanal & & 0.1 \\
\hline 1313 & 2180 & 1,2 & 4-Vinylguaiacol & & 0.4 \\
\hline 1342 & & 1,2 & 1,2-Dihydro-1,1,6-trimethylnaphthalene & & 0.5 \\
\hline 1349 & & 1,2 & Dehydro-ar-ionene & & 0.2 \\
\hline 1358 & 1787 & 1,2 & $(E)$ - $\beta$-Damascenone & & 0.3 \\
\hline 1382 & & 1,2 & $\beta$-Cubebene & & $\mathrm{t}$ \\
\hline 1409 & & 1,2 & 2-Ethyl-1,4-dimethylbenzene & & 0.2 \\
\hline 1410 & & 1,2 & Methyl indole & $\mathrm{t}$ & \\
\hline 1415 & 1722 & 1,2 & Dodecanal & & 0.7 \\
\hline 1450 & 1621 & 1,2 & Widdrene & 4.9 & \\
\hline 1470 & & 1,2 & 2,5-Cyclohexadiene-1,4-dione, 2,6-bis(1,1-dimethylethyl) & & 0.3 \\
\hline 1509 & 1746 & 1,2 & $(Z)-\alpha$-Bisabolene & 1.2 & \\
\hline 1578 & 2150 & 1,2 & Spathulenol & & 1.5 \\
\hline 1651 & 2253 & 1,2 & $\beta$-Eudesmol & 1.9 & 5.4 \\
\hline 1659 & & 1,2 & Valerenol & 1.2 & \\
\hline 1674 & & 1,2 & Tetradecanol & 0.4 & \\
\hline 1758 & 2713 & $1,2,3$ & Tetradecanoic acid & 5.6 & \\
\hline 1771 & & 1,2 & Pentadecanol & & 0.3 \\
\hline 1792 & & 1,2 & 1-Octadecene & 0.6 & \\
\hline 1819 & 2135 & 1,2 & Hexadecanal & & 0.7 \\
\hline 1845 & 2131 & 1,2 & Hexahydrofarnesylacetone & 3.8 & 2.8 \\
\hline 1892 & & 1,2 & 1-Nonadecene & 0.4 & \\
\hline 1900 & 1900 & $1,2,3$ & Nonadecane & 0.8 & \\
\hline 1950 & 2622 & 1,2 & (Z)-Phytol & 1.7 & \\
\hline 1957 & & $1,2,3$ & Hexadecanoic acid ethyl ester & & 0,7 \\
\hline 1958 & 2931 & $1,2,3$ & Hexadecanoic acid & 7.8 & 9.6 \\
\hline 1992 & & 1,2 & 1-Eicosene & 0.6 & \\
\hline 2000 & 2000 & $1,2,3$ & Eicosane & 0.9 & \\
\hline 2023 & 2354 & 1,2 & Octadecanal & 1.1 & \\
\hline 2082 & 2597 & 1,2 & Octadecanol & & 0.2 \\
\hline 2100 & 2100 & $1,2,3$ & Heneicosane & 2.5 & 3.2 \\
\hline 2102 & & 1,2 & 2-Nonadecanone & 0.4 & \\
\hline
\end{tabular}


Table 1. Cont.

\begin{tabular}{|c|c|c|c|c|c|}
\hline 2104 & 3160 & $1,2,3$ & $(Z, Z)-9,12-O c t a d e c a d i e n o i c ~ a c i d ~$ & 5.2 & 2.4 \\
\hline 2132 & 2625 & 1,2 & (E)-Phytol & 2.6 & 3.9 \\
\hline 2194 & & 1,2 & 1-Docosene & 0.2 & \\
\hline 2200 & 2200 & $1,2,3$ & Docosane & 0.4 & 1.4 \\
\hline 2300 & 2300 & $1,2,3$ & Tricosane & 4.4 & 7.3 \\
\hline 2400 & 2400 & $1,2,3$ & Tetracosane & 1.7 & 1.9 \\
\hline 2452 & & 1,2 & Docosanol & 0.4 & \\
\hline 2493 & & 1,2 & 1-Pentacosene & 2.1 & \\
\hline 2500 & 2500 & $1,2,3$ & Pentacosane & 5.4 & 6.5 \\
\hline 2594 & & 1,2 & 1-Hexacosene & & 2.1 \\
\hline 2600 & 2600 & 1,2 & Hexacosane & & 2.9 \\
\hline 2630 & & 1,2 & Tetracosanal & & 0.9 \\
\hline 2658 & & 1,2 & 1-Tetracosanol & & 0.4 \\
\hline 2700 & 2700 & 1,2 & Heptacosane & 6.1 & 9.9 \\
\hline 2728 & & 1,2 & Hexacosanal & & 1.9 \\
\hline 2793 & & 1,2 & 1-Octacosene & & 1.8 \\
\hline 2800 & 2800 & 1,2 & Octacosane & 2.4 & 0.8 \\
\hline 2827 & & 1,2 & Squalene & 1.2 & 1.2 \\
\hline 2900 & 2900 & 1,2 & Nonacosane & 8.3 & 6.5 \\
\hline 3100 & 3100 & 1,2 & Hentriacontane & 9.5 & 7.7 \\
\hline 3200 & 3200 & 1,2 & Dotriacontane & 0.9 & 0.3 \\
\hline \multirow[t]{2}{*}{3300} & 3300 & 1,2 & Tritriacontane & 1.4 & 1.4 \\
\hline & & & Total compounds & 89.7 & 91.5 \\
\hline
\end{tabular}

${ }^{\mathrm{a}} \mathrm{K}_{\mathrm{i} 1}$ : HP 5MS column; ${ }^{\mathrm{b}} \mathrm{K}_{\mathrm{i} 2}$ : HP Innowax column; ${ }^{\mathrm{c}}$ Ident.: 1 = retention index identical to bibliography; 2 = identification based on comparison of MS; 3 = retention time identical to authentic compounds; t: trace amount $<0.05 \%$.

Non-aromatic hydrocarbons were the most abundant compounds in both organs, followed by fatty acids. The most abundant compounds were hentriacontane (S 9.5\%; F 7.7\%) nonacosane (S 8.3\%; F 6.5\%), heptacosane (6.1\%; 9.9\% F), tricosane (S 4.4\%; F 7.3\%), pentacosane (S 5.4\%; F 6.5\%) hexadecanoic acid (S 7.8\%; F 9.6\%), $\beta$-eudesmol (S 1.9\%; F 5.4\%), tetradecanoic acid (S 5.6\%; F 0\%) and (Z,Z)-9,12-octadecadienoic acid (S 5.2\%; F 2.4\%). Data showed differences in the profiles between stems and fruits which shared only eighteen compounds; stems accounted for 38 compounds while fruits for 53. Fruits showed a higher diversity especially in aromatic compounds with 12 compounds versus four in stems. Among the scarce literature available on volatiles in aerial parts of Apocynaceae, excluding flowers, some compounds have been found in leaves and stems of Catharanthus roseus [12,13] and in fruits of Hancornia speciosa [14] (Table 2).

Fifty-five volatiles found in stems and fruits of $C$. europaea are semiochemicals for many insects (Table 2). There are no synomones, which are usually related to pollinators and common in the flowers, while there are 28 attractants, 32 allomones, 21 pheromones and 49 kairomones. In literature there are several papers devoted to the highly specialized role of plant-animal interactions [1] and the semiochemicals present in C. europaea may play key roles in the adaptation of the species to its environment. 
Table 2. Essential oils of the stems and fruits of Caralluma europaea (Guss) N.E.Br. arranged by class.

\begin{tabular}{|c|c|c|c|c|c|c|c|}
\hline \multirow{2}{*}{ Compounds } & \multicolumn{5}{|c|}{ Semiochemicals $^{\text {a }}$} & \multirow{2}{*}{ Antimicrobial $^{\text {b }}$} & \multirow{2}{*}{ Apocynaceae $^{c}$} \\
\hline & A & Al & $\mathbf{P}$ & $\mathbf{K}$ & Sy & & \\
\hline \multicolumn{8}{|c|}{ Aromatic Compounds } \\
\hline \multicolumn{8}{|l|}{ Aldehydes } \\
\hline Benzaldehyde & $\mathrm{x}$ & $\mathrm{x}$ & $\mathrm{x}$ & $\mathrm{x}$ & & & $\begin{array}{l}\mathrm{LC}[12,13] \\
\mathrm{SC}[13]\end{array}$ \\
\hline Phenylacetaldehyde & $\mathrm{x}$ & $\mathrm{x}$ & $\mathrm{x}$ & $\mathrm{x}$ & & & $\begin{array}{l}\text { FH [14] } \\
\text { LC [13] } \\
\text { SC [13] }\end{array}$ \\
\hline 4-Ethylbenzaldehyde & & & & & & $\mathrm{x}$ & \\
\hline \multicolumn{8}{|l|}{ Hydrocarbons } \\
\hline Naphtalene & $\mathrm{x}$ & & $\mathrm{x}$ & $\mathrm{x}$ & & & \\
\hline \multicolumn{8}{|l|}{$\alpha$-Ionene } \\
\hline \multicolumn{8}{|c|}{ 1,2,3,4-tetrahydro-1,5,7-trimethylnaphthalene } \\
\hline \multicolumn{8}{|c|}{ 1,2-Dihydro-1,1,6-trimethylnaphthalene } \\
\hline \multicolumn{8}{|l|}{ Dehydro-ar-ionene } \\
\hline \multicolumn{8}{|l|}{ 2-Ethyl-1,4-dimethylbenzene } \\
\hline \multicolumn{8}{|l|}{ Esters } \\
\hline Methyl benzoate & $\mathrm{x}$ & & $\mathrm{x}$ & $\mathrm{x}$ & & $\mathrm{x}$ & FH [14] \\
\hline \multicolumn{8}{|l|}{ Oxygen containing compounds } \\
\hline 2-Pentylfuran & & & & & & & \\
\hline \multicolumn{8}{|l|}{ Ketones } \\
\hline Acetophenone & $\mathrm{x}$ & $\mathrm{x}$ & $\mathrm{x}$ & $\mathrm{x}$ & & $\mathrm{x}$ & \\
\hline \multicolumn{8}{|c|}{$\begin{array}{l}\text { 2,5-Cyclohexadiene-1,4-dione,2,6-bis(1,1- } \\
\text { dimethyl-ethyl) }\end{array}$} \\
\hline \multicolumn{8}{|l|}{ Phenolic compounds } \\
\hline 4-Vinylguaiacol & & & & & & $\mathrm{x}$ & \\
\hline \multicolumn{8}{|l|}{ Nitrogen containing compounds } \\
\hline Indole & $\mathrm{x}$ & $\mathrm{x}$ & $\mathrm{x}$ & $\mathrm{x}$ & & $\mathrm{x}$ & LC [13] \\
\hline \multicolumn{8}{|l|}{ Methyl indole } \\
\hline \multicolumn{8}{|c|}{$\begin{array}{l}\text { Non-Aromatic Compounds } \\
\end{array}$} \\
\hline \multicolumn{8}{|l|}{ Hydrocarbons } \\
\hline Octane & $\mathrm{x}$ & & & $\mathrm{x}$ & & & \\
\hline 1-Octadecene & & $\mathrm{x}$ & & $\mathrm{x}$ & & & \\
\hline 1-Nonadecene & & $\mathrm{x}$ & & $\mathrm{x}$ & & & \\
\hline Nonadecane & $\mathrm{x}$ & $\mathrm{x}$ & & $\mathrm{x}$ & & & LC [12] \\
\hline 1-Eicosene & & & & $\mathrm{x}$ & & & \\
\hline Eicosane & & & $\mathrm{x}$ & $\mathrm{x}$ & & & LC [12] \\
\hline Heneicosane & $\mathrm{x}$ & & & $\mathrm{x}$ & & & \\
\hline 1-Docosene & & & & $\mathrm{x}$ & & & \\
\hline Docosane & & $\mathrm{x}$ & $\mathrm{x}$ & $\mathrm{x}$ & & & LC [12] \\
\hline Tricosane & $\mathrm{x}$ & $\mathrm{x}$ & $\mathrm{x}$ & $\mathrm{x}$ & & & LC [12] \\
\hline
\end{tabular}


Table 2. Cont.

\begin{tabular}{|c|c|c|c|c|c|c|}
\hline Tetracosane & $\mathrm{x}$ & $\mathrm{x}$ & $\mathrm{x}$ & $\mathrm{x}$ & & LC [12] \\
\hline 1-Pentacosene & & & & $\mathrm{x}$ & & \\
\hline Pentacosane & $\mathrm{x}$ & $\mathrm{x}$ & $\mathrm{x}$ & $\mathrm{x}$ & & \\
\hline 1-Hexacosene & & & & $\mathrm{x}$ & & \\
\hline Hexacosane & $\mathrm{x}$ & $\mathrm{x}$ & & $\mathrm{x}$ & & \\
\hline Heptacosane & & $\mathrm{x}$ & & $\mathrm{x}$ & & \\
\hline 1-Octacosene & & $\mathrm{x}$ & & & & \\
\hline Octacosane & & $\mathrm{x}$ & & $\mathrm{x}$ & & \\
\hline Nonacosane & $\mathrm{x}$ & $\mathrm{x}$ & & $\mathrm{x}$ & & \\
\hline Hentriacontane & & & & $\mathrm{x}$ & & \\
\hline Dotriacontane & & & & $\mathrm{x}$ & & \\
\hline Tritriacontane & & & & $\mathrm{x}$ & & \\
\hline \multicolumn{7}{|l|}{ Alcohols } \\
\hline 1-Octen-3-ol & $\mathrm{x}$ & $\mathrm{x}$ & $\mathrm{x}$ & $\mathrm{x}$ & & $\mathrm{FH}[14]$ \\
\hline Tetradecanol & $\mathrm{x}$ & & & $\mathrm{x}$ & $\mathrm{x}$ & \\
\hline Pentadecanol & & & & $\mathrm{x}$ & $\mathrm{x}$ & \\
\hline Octadecanol & & & & $\mathrm{x}$ & & FH [14] \\
\hline Docosanol & & & & $\mathrm{x}$ & & \\
\hline 1-Tetracosanol & & & & & & \\
\hline \multicolumn{7}{|l|}{ Aldehydes } \\
\hline Heptanal & $\mathrm{x}$ & $\mathrm{x}$ & $\mathrm{x}$ & $\mathrm{x}$ & & \\
\hline Octanal & $\mathrm{x}$ & $\mathrm{x}$ & $\mathrm{x}$ & $\mathrm{x}$ & $\mathrm{x}$ & $\begin{array}{l}\text { LC [13] } \\
\text { SC [13] }\end{array}$ \\
\hline Nonanal & $\mathrm{x}$ & $\mathrm{x}$ & $\mathrm{x}$ & $\mathrm{x}$ & $\mathrm{x}$ & $\begin{array}{l}\text { LC [12] } \\
\text { FH [14] }\end{array}$ \\
\hline Decanal & $\mathrm{x}$ & $\mathrm{x}$ & $\mathrm{x}$ & $\mathrm{x}$ & $\mathrm{x}$ & $\begin{array}{l}\text { LC [12] } \\
\text { FH [14] }\end{array}$ \\
\hline (E)-2-Decenal & $\mathrm{x}$ & $\mathrm{x}$ & $\mathrm{x}$ & $\mathrm{x}$ & & $\begin{array}{c}\text { LC }[12,13] \\
\text { SC }[13] \\
\text { FH }[14]\end{array}$ \\
\hline Undecanal & $\mathrm{x}$ & $\mathrm{x}$ & & $\mathrm{x}$ & $\mathrm{x}$ & LC [12] \\
\hline Dodecanal & & $\mathrm{x}$ & $\mathrm{x}$ & $\mathrm{x}$ & & LC [12] \\
\hline Hexadecanal & $\mathrm{x}$ & $\mathrm{x}$ & & $\mathrm{x}$ & $\mathrm{x}$ & FH [14] \\
\hline Octadecanal & & & & $\mathrm{x}$ & $\mathrm{x}$ & \\
\hline Tetracosanal & & & & & & \\
\hline Hexacosanal & & & & & & \\
\hline \multicolumn{7}{|l|}{ Ketones } \\
\hline \multicolumn{7}{|l|}{ (E)- $\alpha$-Damascenone } \\
\hline Hexahydrofarnesylacetone & & & & $\mathrm{x}$ & & $\begin{array}{l}\text { LC [13] } \\
\text { SC [13] }\end{array}$ \\
\hline 2-Nonadecanone & & & & & & \\
\hline \multicolumn{7}{|c|}{ Monoterpene Hydrocarbons } \\
\hline$\alpha$-Pinene & $\mathrm{x}$ & $\mathrm{x}$ & $\mathrm{x}$ & $\mathrm{x}$ & $\mathrm{x}$ & \\
\hline
\end{tabular}


Table 2. Cont.

\begin{tabular}{|c|c|c|c|c|c|c|}
\hline \multicolumn{7}{|l|}{ Oxygenated Monoterpenes } \\
\hline Safranal & & & & & & LC [13] \\
\hline$\alpha$-Cyclocitral & & & & & & LC [13] \\
\hline \multicolumn{7}{|l|}{ Sesquiterpene hydrocarbons } \\
\hline \multicolumn{7}{|l|}{$\beta$-Cubebene } \\
\hline \multicolumn{7}{|l|}{ Widdrene } \\
\hline \multicolumn{7}{|l|}{ (Z)- $\alpha$-Bisabolene } \\
\hline \multicolumn{7}{|l|}{ Oxygenated sesquiterpenes } \\
\hline Spathulenol & $\mathrm{x}$ & & & & $\mathrm{x}$ & \\
\hline$\beta$-Eudesmol & & $\mathrm{x}$ & & & & \\
\hline \multicolumn{7}{|l|}{ Valerenol } \\
\hline \multicolumn{7}{|l|}{ Fatty acids } \\
\hline Tetradecanoic acid & & $\mathrm{x}$ & & $\mathrm{x}$ & $\mathrm{x}$ & LC [12] \\
\hline Hexadecanoic acid & $\mathrm{x}$ & $\mathrm{x}$ & $\mathrm{x}$ & $\mathrm{x}$ & $\mathrm{x}$ & LC [12] \\
\hline$(Z, Z)-9,12-$ Octadecadienoic acid & $\mathrm{x}$ & $\mathrm{x}$ & $\mathrm{x}$ & $\mathrm{x}$ & $\mathrm{x}$ & LC [12] \\
\hline \multicolumn{7}{|l|}{ Esters } \\
\hline Hexadecanoic acid ethyl ester & & & & $\mathrm{x}$ & & $\begin{array}{l}\text { LC [13] } \\
\text { SC [13] }\end{array}$ \\
\hline \multicolumn{7}{|l|}{ Diterpenes } \\
\hline (Z)-Phytol & & & & & $\mathrm{x}$ & LC [13] \\
\hline (E)-Phytol & & $\mathrm{x}$ & & $\mathrm{x}$ & $\mathrm{x}$ & \\
\hline \multicolumn{7}{|l|}{ Triterpenes } \\
\hline Squalene & $\mathrm{x}$ & $\mathrm{x}$ & & $\mathrm{x}$ & $\mathrm{x}$ & \\
\hline
\end{tabular}

a Semiochemicals: (A: Attractant; Al: Allomone; K: Kairomone; P: Pheromone; Sy: Synomone) [15]. ${ }^{\mathrm{b}}$ Antimicrobial: Antimicrobial Data of Drugs, Natural Compounds and Essential Oils [16]. ' Aerial parts of other Apocynaceae: LC: Leaves of Catharanthus roseus [12,13]; SC: Stems of Catharanthus roseus [13]; FH: Fruits of Hancornia speciosa [14].

Plant semiochemicals are known to produce a wide range of behavioral responses in insects. Some insects sequester or acquire host plant compounds and use them as sex pheromones or sex pheromones precursors. Other insects produce or release sex pheromones in response to specific host plant cues, and chemicals from host plants often synergistically enhance the response of an insect to sex pheromones [17]. It is interesting to note that at least four of the most abundant volatiles found in $C$. europaea (pentacosane, hexacosane, heptacosane and hexadecanoic acid) are male pheromones for Danaus chrysippus [18], a butterfly whose larvae feed on plants rich in cardenolides like Apocynaceae and Moraceae [19]. In a recent paper Pisciotta et al. [20] observed that D. chrysippus in Lampedusa island oviposited only on the fruits of C. europaea (Figure 1) and that larvae fed on its fruits and stems (Figure 2). 
Figure 1. Egg of Danaus chrysippus on a fruit of C. europaea in Lampedusa Island (Photo by P. Zito).

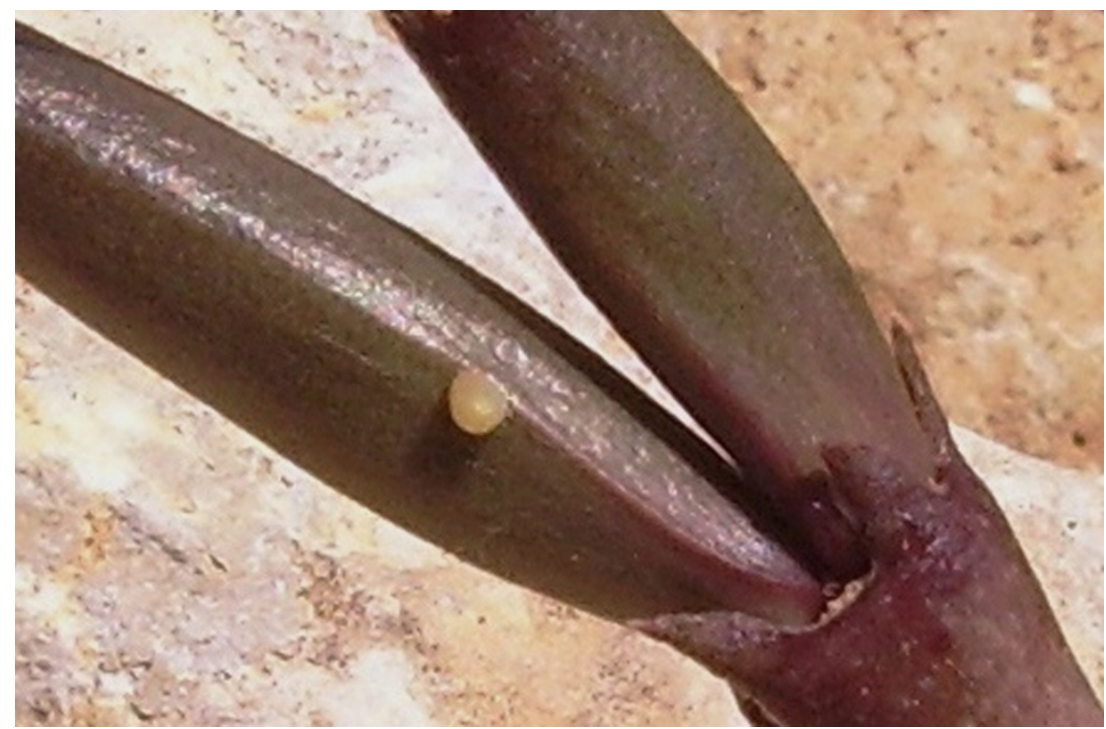

Figure 2. Larvae of $D$. chrysippus feeding on fruits of $C$. europaea in Lampedusa Island (Photo by P. Zito).

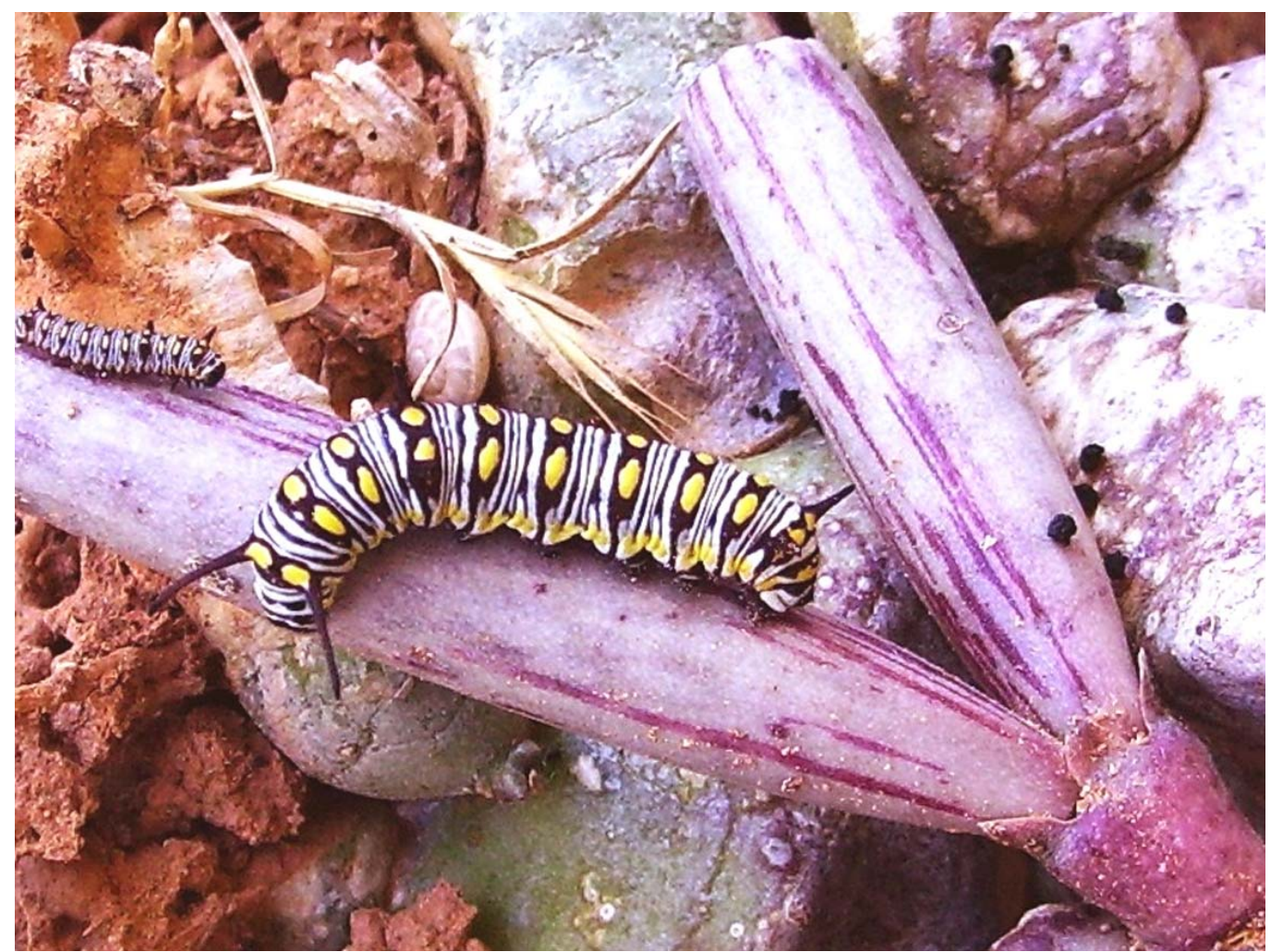

According to Reddy and Guerrero [17] the effects of host plants on pheromone behavior appear to be part of male strategies to maximize encounters with females as well as of female strategies to gain access to new feeding and oviposition sites. It is possible that the male pheromones guide the female of D. chrysippus to the ovipostion site and influences the feeding behavior of the larvae, thus having a negative effect on the fitness of the plant. Twenty one volatiles found in C. europaea are antimicrobial 
agents (Table 2) and fatty acids are among the main constituents. (Z,Z)-9,12-Octadecadienoic acid, tetradecanoic acid and hexadecanoic acid show antimicrobial activity against Candida albicans, Clostridium welchii and Staphylococcus aureus [21,22]. Walters at al. [23] also indicated that (Z,Z)-9,12-octadecadienoic acid has antifungal activities on the plant pathogenic fungi: Rhizoctonia solani, Pythium ultimum, Pyrenophora avenae and Crinipellis perniciosa. According to GonzálezLamothe et al. [24] plants are continuously in contact with different microorganisms, including viruses, bacteria and fungi many of which are pathogens that affect plant development, reproduction and ultimately yield production.

\section{Experimental}

Plant material was collected in Lampedusa Island (Italy, 35 $29^{\prime} 28^{\prime \prime}$ and $35^{\circ} 21^{\prime} 39^{\prime \prime} \mathrm{N}-12^{\circ} 30^{\prime} 54^{\prime \prime}$ and $12^{\circ} 37^{\prime} 55^{\prime}$ " E) from plants growing in the "Isola dei Conigli" area at an altitude of $100 \mathrm{~m}$ a.s.l. Stems and fruits were collected in April 2008, placed in paper bags and kept at $4 \pm 1{ }^{\circ} \mathrm{C}$ for three hours before the hydrodistillation. Clones of the plants used are cultivated at the Botanical Garden of Palermo and a voucher specimen ( $\left.\mathrm{N}^{\circ} \mathrm{PAL} / \mathrm{MS} / 1112\right)$ was deposited in the Herbarium, Orto Botanico, Palermo, Italy.

Air dried stems (23.64 g) and fruits (41.67 g) were hand-cut into small fragments and hydrodistilled in a Clevenger-type apparatus for three hours as previously described by Riela et al. [25]. The waxy oils were collected by $n$-pentane extraction, dried over anhydrous sodium sulphate and removal of the solvent. The essential oil yields was $0.38 \mathrm{mg}$ (1.60\%) and $4.90 \mathrm{mg}$ (11.75\%) for stems and fruits, respectively. The oil samples, characterized by a typical malodorous odour, were stored in a refrigerator at $-10{ }^{\circ} \mathrm{C}$ until analysed. Analyses of essential oils were performed on a Perkin Elmer Sigma 115 gas chromatograph (GC) equipped with two different polarity-fused silica capillary columns: HP 5MS and HP Innowax, both $30 \mathrm{~m}$ long x $0.25 \mathrm{~mm}$ ID; $0.25 \mu \mathrm{m}$ film thickness. Temperature program: initial temperature, $40{ }^{\circ} \mathrm{C}$; hold $5 \mathrm{~min}$; temperature rate $4{ }^{\circ} \mathrm{C} \mathrm{min}{ }^{-1}$, final temperature $250{ }^{\circ} \mathrm{C}$; hold $30 \mathrm{~min}$; column flow rate $1.0 \mathrm{~mL} \mathrm{He} \mathrm{min}^{-1}$; injector and detector temperatures $260{ }^{\circ} \mathrm{C}$ and $280{ }^{\circ} \mathrm{C}$, respectively. Injection volume: $1.0 \mu \mathrm{L}$ of diluted samples $(1 / 100 \mathrm{v} / \mathrm{v}$, in $n$-pentane) in the splitless mode. GC/MS analyses were performed on a Agilent 6850 Series II apparatus using an HP-5 fused silica capillary column (30 m long $\times 0.25 \mathrm{~mm}$ ID; $0.33 \mu \mathrm{m}$ film thickness), connected to a quadrupole detector operating in electron impact (EI) mode at $70 \mathrm{eV}$; electron multiplier energy 2,000 V. Most constituents were identified by gas chromatography by comparison of their retention indices $\left(\mathrm{R}_{\mathrm{i}}\right)$ with either those of the literature $[26,27]$ or with those of authentic compounds available in our laboratories. The retention indices were determined in relation to a homologous series of $n$-alkanes $\left(\mathrm{C}_{8}-\mathrm{C}_{28}\right)$ under the same operating conditions. All the compounds were identified by comparison of their mass spectra on both columns with either those stored in NIST 02 and Wiley 275 libraries or with mass spectra from the literature [26,28] and a home made library. Component relative concentrations were calculated based on GC peak areas without using correction factors. Pure commercial essential oil components used as standards for GC-FID analyses were obtained from Aldrich and Fluka. 


\section{Conclusions}

Among the volatile compounds found in C. europaea several have semiochemical and antimicrobial activities. As regards to semiochemicals they may play a role in the defence of the plant against herbivores by discouraging foraging on stems and fruits [1]. It is interesting to note that, as reported by Dudareva et al. [1], some volatiles may not always be beneficial to the plant. This is the case of the four pheromones which attract Danaus chrysippus to oviposit on fruits and to feed on stems and fruits. These pheromones play a role as kayromones at least in these combination of species: C. europaea $D$. chrysippus. The presence of antimicrobials could increase the fitness of the plant by arresting the spread of pathogens. Further investigations on C. europaea essential oils would be interesting to test the actual antimicrobial potential and to verify also its pharmaceutical interest.

\section{Acknowledgements}

We would like to thank the Director G. Nicolini and the staff of Riserva Naturale Orientata Isola di Lampedusa for the assistance and the logistic support. The GC and GC-MS spectra were performed at the "C.R.A.S." of the University "Federico II", Napoli. The assistance of the staff is gratefully appreciated.

\section{References and Notes}

1. Dudareva, N.; Negre, F.; Nagegowda, D.A.; Orlova, I. Plant Volatiles: Recent Advances and Future Perspectives. Crit. Rev. Plant Sci. 2006, 25, 417-440.

2. Suresh, B.K.; Rama, S.R.; Vyasa, R.S.; Madhusudana, R.J.; Siva, R.S. A new pregnane steroid from the stems of Caralluma umbellata. J. Asian Nat. Prod. Res. 2008, 10, 1013-1016.

3. Abdel-Sattar, E.; Harraz, F.M.; Al-Ansari, S.M.A.; El-Mekkawy, S.; Ichino, C.; Kiyohara H.; Ishiyama, A.; Otoguro, K.; Omura, S.; Yamada, H. Acylated pregnane glycosides from Caralluma tuberculata and their antiparasitic activity. Phytochemistry 2008, 69, 2180-2186.

4. Kunert, O.; Rao, V.G.; Babu, G.S.; Sujatha, P.; Sivigamy, M.; Anuradha, S.; Rao, B.V.; Kumar, B.R.; Alex, R.M.; Schuhly, K.; Kuhnelt, D.; Rao, G.V.; Rao, A.V. Pregnane glycosides from Caralluma adscendens var. fimbriata. Chem. Biodiv. 2008, 5, 239-250.

5. Abdel-Sattar, E.; Ahmed, A.A.; Hegazy, M.E.F.; Farag, M.A.; Al-Yahya, M.A.A. Acylated pregnane glycosides from Caralluma russelliana. Phytochemistry 2007, 68, 1459-1463.

6. Bader, A.; Braca, A.; De Tommasi, N.; Morelli, I. Further constituents from Caralluma negevensis. Phytochemistry 2003, 62, 1277-1281.

7. Kamil, M.; Jayaraj, A.F.; Ahmad, F.; Gunasekhar, C.; Samuel, S.; Chan, K.; Habibullah M.; Attas, A. Separation of flavonoids from Caralluma arabica using high-speed counter-current chromatography. J. Pharm. Pharmacol. 2000, 52, 265.

8. Ramesh, M.; Rao, Y.N.; Kumar, M.R.; Mohan G.K.; Kumar, B.R.; Roa, A.V.N.A.; Krishna, M.R.; Reddy, B.M. Flavone glycoside from three Caralluma species. Biochem. Syst. Ecol. 1999, 27, 85-86.

9. Meve, U.; Heneidak, S. A morphological, karyological and chemical study of the Apteranthes (Caralluma) europaea complex. Biol. J. Linnean Soc. 2005, 149, 419-432. 
10. Formisano, C.; Senatore, F.; Della Porta, G.; Scognamiglio, M.; Bruno, M.; Maggio, A.; Rosselli, S.; Zito, P.; Sajeva, M. Headspace Volatile Composition of the Flowers of Caralluma europaea N.E. Br. (Apocynaceae). Molecules 2009, 14, 4597-4613.

11. Sajeva, M.; Costanzo, M. Succulents-The Illustrated Dictionary; Cassel plc: London, UK, 1994; pp. 58-59.

12. Pandey-Rai, S.; Mallavarapu, G.R.; Naqvi, A.A.; Yadav, A.; Kumar, R.S.; Srivastava, S.; Singh, D.; Mishra, R.; Kumar, S. Volatile components of Leaves and Flowers of Periwinkle Catharanthus roseus (L.) G. Don from New Delhi. Flavour Fragr. J. 2006, 21, 427-430.

13. De Pinho, P.G.; Gonçalves, R.S.; Valentão, P.; Pereira, D.M.; Seabra, R.M.; Andrade, P.B.; Sottomayor, M. Volatile Composition of Catharanthus roseus (L.) G. Don using Solid Phase Microextraction and Gas Chromatography\Mass Spectrometry. J. Pharm. Biomed. Anal. 2009, 49, 674-685.

14. Sampaio, T.S.; Nogueira, P.C.L. Volatile Components of Mangaba Fruit (Hancornia speciosa Gomes) at Three Stages of Maturity. Food Chem. 2006, 95, 606-610.

15. El-Sayed, A.M. The Pherobase: Database of Insect Pheromones and Semiochemicals. http://www.pherobase.com/, accessed on 28 December 2009.

16. Pauli, A. Amicbase-Databases: Collections of Antimicrobial Data of Drugs, Natural Compounds and Essential Oils. www.reviewscience.com/, accessed on 28 December 2009.

17. Reddy, G.V.P.; Guerrero, A. Interactions of insect pheromones and plant semiochemicals. Trends Plant Sci. 2004, 9, 253-261.

18. Schulz, S.; Boppré, M.; Vane-Wright, R.I. Specific mixture of secretions from male scent organs of African milkweed butterflies (Danainae). Phil. Trans. R. Soc. Lond. B. 1993, 342, 161-181.

19. Ackery, R.I.; Vane-Wrigth, R.I. Milkweed Butterflies, Their Cladistics and Biology; British Museum (Natural History): London, UK, 1984; pp. 80-92.

20. Pisciotta, S.; Zito, P.; Sajeva, M. Danaus Chrysippus (Linnaeus, 1758) (Lepidoptera Nymphalidae) Larvae Feeding on Caralluma europaea (Guss.) N.E. Br. (Asclepiadaceae) in Lampedusa Island. Nauralista sicil. 2008, 32, 241-251.

21. Bodoprost, J.; Rosemeyer, H. Analysis of Phenacylester Derivatives of Fatty Acids from Human Skin Surface Sebum by Reversed-Phase HPLC: Chromatograpic Mobility as a Function of Physico-Chemical Properties. Int. J. Mol. Sci. 2007, 8, 1111-1124.

22. Cañas-Rodriguez, A.; Smith, H.W. The Identification of the Antimicrobial Factors of the Stomach Contents of Sucking Rabbits. Biochem. J. 1966, 100, 79-82.

23. Walters, D.; Raynor, L.; Mitchell, A.; Walker, R.; Walker, K. Antifungal activities of four fatty acids against Plant Pathogenic fungi. Mycopathologia 2004, 157, 87-90.

24. González-Lamothe, R.; Mitchell, G.; Gattuso, M.; Diarra, M.S.; Malonin, F.; Bourab, K. Plant Antimicrobial Agents and their effects on Plant and Human Pathogenes. Int. J. Mol. Sci. 2009, 10, 3400-3419.

25. Riela, S.; Bruno, M.; Formisano, C.; Rigano, D.; Rosselli, S.; Saladino, M.L.; Senatore, F. Studies on the effects of solvent free microwave extraction on the chemical composition of essential oil of Calamintha nepeta (L.) Savi compared with conventional method. J. Sep. Sci. 2008, 31, 1110-1117. 
26. Jennings, W.; Shibamoto, T. Qualitative Analysis of Flavor and Fragrance Volatiles by Glass Capillary Chromatography; Academic Press: New York, NY, USA, 1980.

27. Davies, N.W. Gas Cromatographyc detection indexes of monoterpenes and sesquiterpenes on methyl silicone and Carbowax 20 M phases. J. Chromatogr. A. 1990, 503, 1-24.

28. Adams, R.P. Identification of Essential Oils Components by Gas Chromatography/Mass Spectrometry, 4th ed.; Allured Publ. Corp.: Carol Stream, IL, USA, 2007.

Sample Availability: Samples of the compounds are available from the authors.

(C) 2010 by the authors; licensee Molecular Diversity Preservation International, Basel, Switzerland. This article is an open-access article distributed under the terms and conditions of the Creative Commons Attribution license (http://creativecommons.org/licenses/by/3.0/). 